\title{
THE PERCEIVED EFFECTIVENESS OF STUDENT ENGAGEMENT
STRATEGIES IN OPEN AND DISTANCE LEARNING
}

\author{
Zaemah Abdul \\ Kadir $^{1+}$ \\ (D) Faizah Mohamad ${ }^{2}$ \\ Dor Azah Mohd \\ Rathi $^{3}$
}

iD Muhammad Haziq Abdul Rashid ${ }^{4}$

\section{Article History}

Received: 10 September 2021 Revised: 25 October 2021 Accepted: 22 November 2021 Published: 16 December 2021

\section{Keywords}

Student engagement Strategies

Learner-to-learner Interactions Learner-to-content Interactions Learner-to-instructor Interactions

Online learning COVID 19.

\author{
${ }^{1,2,3}$ Akademi Pengajian Bahasa, University Technology MARA, Shah Alam, \\ Malaysia. \\ 'Email:zaemah@uitm.edu.my Tel:+60123035796 \\ 2Email: fareema@uitm.edu.my Tel:+60139818809 \\ ${ }^{s}$ Email: noraz081@uitm.edu.my Tel:+0126262642 \\ 'Human Capital Management Department, Domino's Pizza Malaysia, \\ Malaysia. \\ ${ }^{*}$ Email: haziq.abdrashid@dominos.com.my Tel:+01110887281
}

\section{$A B S T R A C T$}

Student engagement is critical in online learning because it makes students feel more satisfied and motivated to learn. This study investigated how university students perceive various engagement tactics employed in online courses during the Covid 19 pandemic. Student engagement was measured using Moore's interaction framework. It implemented non-experimental quantitative research design through a survey with descriptive and causal-comparative approaches. A 29-item survey on learner-to-learner, learner-to-instructor, and learner-to-content engagement strategies was completed by 181 students from School of Engineering at Universiti Teknologi MARA. The students considered learner-to-content interactions to be the most engaging technique, according to the research. Learner-to-instructor interactions were the next most engaging method, while learner-to-learner interactions were the least engaging. Additionally, the most engaging technique is for them to search for and select appropriate materials in the learner-to-content category depending on their interests. Working jointly using online communication technologies to accomplish case studies, projects, or reports was deemed the most interesting technique by students in the learner-to-learner category. In the learner-to-instructor category, an email reminder or periodical notification is likewise regarded as the most engaging method. All three engagement mechanisms were shown to be interrelated, with learner-to-learner interactions heavily influencing learner-to-learner interactions. Mechanical engineering students were shown to be better at perceiving and implementing these tactics than students from the colleges of electrical, chemical, and civil engineering. It is believed that the findings of the present study will assist teachers and lecturers in increasing their participation in online courses.

Contribution/ Originality: This study contributes to the existing literature on student engagement strategies in the open and distance learning. In addition, these study documents strategies that students perceive as most valuable and least valuable in the online learning environment.

\section{INTRODUCTION}

The new normal of education has urged higher learning institutions to opt for open and distance learning $(\mathrm{ODL})$ as the way for teaching and learning process as the traditional face to face (F2F) classes have to be discontinued due to the pandemic of Covid 19 since March 2020. Many students found it was difficult to adapt to ODL based on a study done by Ismail, Bakar, and Wafa (2020) who discovered that the students cited issues such as 
Internet connectivity, a non-conducive learning environment and lack of technological expertise as the main challenges to face ODL. Even the lecturers need to equip themselves with some IT skills to aid them in conducting synchronous or asynchronous online learning with the use of digital devices, technology tools and Internet connections. Besides that, the interaction between instructors-student, students and students and students and course content help to facilitate learning in a distance education environment (Moore, Warner, \& Jone, 2016). Therefore, it is very important to have engagement strategy which could help the students to overcome their difficulties in ODL and at the same time, they can be motivated and active when having online classes.

According to Martin and Bolliger (2018) student engagement can be defined as a student's interest and attempt to accomplish success towards learning, understanding or mastering the knowledge, skills or crafts in the academic setting. This has a direct impact on students' achievement. Meanwhile, interaction is considered an essential component of successful online learning (Mehall, 2020). This was supported by Ali (2020) who found that the three types of interactions, namely learner-to-learner, learner-to-instructor, and learner-to-content are necessary for effective online education.

In ODL, students oversee their own learning and they should be prepared to face any challenges. There are some strategies that could be engaged by students to help them overcome problems in ODL. Therefore, this study aims to investigate engagement strategies used by students in online classes. This could help instructors to construct effective lessons to ensure students can perform well and boost their level of motivation in overcoming challenges in ODL. Thus, the research objectives for this study are:

i. To identify strategies that students perceive to be important in enhancing learner-learner, learnerinstructor, and learner-content engagement in the online environment.

ii. To determine strategies that students perceive as most valuable and least valuable in the online learning environment.

iii. To investigate correlations between learner-to-learner, learner-to-instructor and learner-to-content engagement strategies.

iv. To determine differences in the student perceptions towards the engagement strategies with the course enrolled.

\section{LITERATURE REVIEW}

Moore (1993) identified three types of interaction inherent in effective online courses which are learner-tolearner interaction, learner-to-instructor interaction, and learner-to-content interaction. According to Moore, learner-to-learner interaction is extremely valuable for online learning, and it leads to student engagement. To keep online students from becoming bored or isolated in the learning environment, it is critical to design activities that promote engagement. Learner-to-learner interaction is extremely valuable for online learning as it encourages student engagement. This idea is in line with the social presence in Community of Inquiry (CoI) Framework in research related to online learning Garrison, Anderson, and Archer (1999). Learner-to-content engagement is the process of intellectually interacting with the content, which can change a learner's understanding and perspectives (Moore, 1993). When teaching online, instructors must choose appropriate content to promote engagement. Online students should not be given a list of resources; rather, instructors should design authentic activities that allow them to do or complete the tasks from various perspectives. Instructors also should encourage students to use relevant information wisely throughout the learning process. Learner-to-instructor interaction also plays an important for an effective online course as a student would normally contact his instructors such as for assignments, feedback, materials, and assessments. Garrison et al. (1999) describe this as teaching presence, and they define it as the design, facilitation, and direction of cognitive and social processes for the purpose of realizing personally meaningful and educationally worthwhile learning outcomes. 
Martin and Bolliger (2018) stated that student engagement boosts student satisfaction, motivates students to learn, reduces feelings of isolation, and improves student performance in online courses. They investigated learnerto-learner, learner-to-instructor, and learner-to-content engagement strategies. It was found that learner-toinstructor engagement strategies were considered as the most beneficial by the students in the online environment. In the learner-to-learner category, icebreaker/introduction discussions and working collaboratively using online communication tools were rated as the most beneficial engagement strategies. Their research also showed that sending regular announcements or email reminders and providing grading rubrics for all assignments were rated as the most beneficial in the learner-to-instructor category whereas in the learner-content category, working on realworld projects and having discussions with structured or guiding questions were the most beneficial.

A study was conducted on the effects of student engagement, student satisfaction, and perceived learning in online learning environments by Gray and DiLoreto (2016). This study indicated a significant relationship between course structure and perceived student learning. Their findings showed that while student interaction had no statistically significant effect on student satisfaction, instructor presence had a statistically significant effect on perceived student learning. Furthermore, the data also showed that instructor presence did influence student satisfaction. The study indicated that course design, organization, planning, social interaction, engagement, and instructor presence were important aspects of online learning. Thus, students have a more positive attitude toward what they have learned and their overall satisfaction with the course if they are given opportunities to interact with one another and with their instructors.

Another study that investigated engagement strategies among higher education students was conducted by Abou-Khalil et al. (2021). The study conducted was based on Moore's interaction framework for distance education. Their research showed that student-content engagement strategies such as screen sharing, summaries, and class recordings were perceived as the most effective. In student-teacher strategies, question-answer sessions, as well as a reminder, were considered the most effective. The least effective student-student strategies were group chat and collaborative work.

Based on participatory learning theory, the goals of the research conducted by Haron, Natrah, and Harun (2017) were to investigate possible components of participatory engagement to influence the process of engagement in an e-learning community. The conceptual model integrates individual or group learning, collaborative learning, and emphasises the importance of interaction between learners and educators in facilitating each other's participation in the e-learning community. The research identified the importance of a participatory engagement component within the e-learning community in stimulating a strong and sustainable e-learning community. According to them, a strong and sustainable e-learning community could be accomplished by incorporating a participatory learning model into the e-learning community to increase engagement. The introduction of participatory engagement components is essential in promoting engagement within the e-learning community.

Instructors employ a variety of strategies to promote learning and actively engage students in online courses. Martin, Wang, and Sadaf (2018) examined student perception on the helpfulness of the twelve different facilitation strategies used by instructors on establishing instructor presence, instructor connection, engagement and learning. Instructors' timely response to questions and instructors' timely feedback on assignments/projects were rated the highest in all four constructs among the 12 facilitation strategies (instructor presence, instructor connection, engagement and learning). In addition, the interactive visual syllabi of the course were rated the lowest, and the video-based introduction and instructors' use of synchronous sessions to interact were rated the lowest of the four constructs. They also found that there was a difference between gender and discipline on all four constructs.

In response to the COVID-19 pandemic, all levels of education ranging from kindergarten to tertiary education have migrated from face-to-face learning to fully online education. In Malaysia, Azlan et al. (2020) conducted a study among medical students to investigate their readiness in embracing open and distance learning. They discovered that while students preferred face-to-face, physical teaching, they were able to adapt to the new norm of 
e-learning. Pre-recorded lectures and viewing videos of practical sessions and answering short questions, were considered beneficial. However, hands-on practical and clinical experience were not replaceable. Students also faced challenges in online learning such as distractions, lack of engagement, mental stress, technical problems and limited data plans.

Zhang et al. (2020) examined how university students adapted to ODL in China. They investigated the relationship between adaptability, academic emotion, and student engagement. According to Zhang et al. (2020) student engagement and the ability to respond to changes were significantly positively correlated with positive academic emotion and negatively correlated with negative academic emotion. Furthermore, adaptability not only directly predicted student engagement, but also affected student engagement through the chain mediation of positive academic emotion and negative academic emotion.

Khlaif, Salha, and Kouraichi (2021) stated that various factors influenced student engagement in online learning among university students in Palestine during the crisis including infrastructure factors, cultural factors, digital inequality, and the threat to digital privacy. Cultural factors influenced females more than males because of parental culture and bias against females using online learning compared to male students. The presence of teachers and the quality of content were the most important factors that influenced student engagement, whereas parental concerns, norms, and traditions emerged as the most important factors in the crisis, influencing engagement. The students also perceived online teaching and learning during the crisis widened digital inequality and jeopardised students' digital privacy, thus, negatively influencing student engagement.

\section{METHODOLOGY}

In this study, a non-experimental quantitative research method based on a survey design was used. Descriptive and causal-comparative approaches were applied to analyze and discuss the data generated from frequency distribution, Pearson correlation and one-way ANOVA tests. The selection of this research design was deemed suitable to accomplish the research objectives. The application of Moore's interaction framework was used to measure the student engagement strategies whereas the survey instrument was adapted from Martin and Bolliger (2018). The questionnaire consisted of four sections: Section A, Section B, Section C and Section D. Section A gathered information on demographic data which were gender, faculty, and levels of study. Section B covered the respondents' perception towards learner-to-learner strategy and Section C collected information on the perceptions towards learner-to-instructor in ODL. Finally, Section D focused on learner-content engagement strategies. The questionnaire was distributed to students from the School of Engineering as this was the first school established in University Teknologi MARA. The school consists of four engineering faculties which are Faculty of Chemical Engineering, Faculty of Mechanical Engineering, Faculty of Civil Engineering and Faculty of Mechanical Engineering. The researchers received 181 responses and the data gathered were then analysed using SPSS. The findings were reported in descriptive and inferential statistics. The significance level was set at 0.05.

\section{RESULTS AND DISCUSSION}

\subsection{Demography}

Out of 181 respondents, $29.8 \%$ (54) enrolled in Chemical Engineering programme and this was closely followed by those in Civil Engineering programme at 26.5\% (48) and by those in Electrical Engineering programme at 24.9\% (45). Meanwhile, the remaining 18.8\% (34) enrolled in Mechanical Engineering programme. Table 1 shows the summary in percentage and frequency of the programmes enrolled by engineering students.

In the effort of addressing the first research question on the strategies that the students perceive to be important in enhancing learner-to-learner, learner-to-instructor and learner-to-content engagement strategies in the online environment, a frequency distribution was conducted on Sections B, C and D of the questionnaire. From 
the responses, the most engaging and least engaging aspects for the respective engagement strategies (learner-tolearner, learner-to-instructor and learner-to-content) were identified and highlighted.

Table-1. Programmes enrolled by engineering students.

\begin{tabular}{|c|c|c|c|c|c|}
\hline \multicolumn{6}{|c|}{ Programmes Enrolled } \\
\hline & & Frequency & Percent & Valid Percent & Cumulative Percent \\
\hline \multirow[t]{5}{*}{$\overline{\text { Valid }}$} & Chemical Engineering & 54 & 29.8 & 29.8 & 29.8 \\
\hline & Civil Engineering & 48 & 26.5 & 26.5 & 56.4 \\
\hline & Electrical Engineering & 45 & 24.9 & 24.9 & 81.2 \\
\hline & Mechanical Engineering & 34 & 18.8 & 18.8 & 100.0 \\
\hline & Total & 181 & 100.0 & 100.0 & \\
\hline
\end{tabular}

\subsection{Learner-to-Learner Engagement}

Table 2 shows the summary of responses in percentage and frequency on learner-to-learner engagement strategy.

Table-2. Summary of responses in percentage and frequency on learner-to-learner engagement strategy.

\begin{tabular}{l|c|c|c|c|c}
\hline Statements & \multicolumn{5}{c}{ Percentage (\%) / Frequency (N) } \\
\cline { 2 - 6 } & Never & Rarely & Sometimes & Very Often & Always \\
\hline [We enjoy meeting informally to share common & 2.8 & 7.7 & 32.6 & 37.6 & $19.3(35)$ \\
interests] & $(5)$ & $(14)$ & $(59)$ & $(68)$ & \\
\hline [We were given the opportunity to introduce & 2.8 & 13.3 & 31.5 & 34.8 & 17.7 \\
ourselves using an icebreaker discussion.] & $(5)$ & $(24)$ & $(57)$ & $(63)$ & $(32)$ \\
\hline [We were able to moderate discussions] & 6 & 9.4 & 27.1 & 42.0 & 21.0 \\
& $(1)$ & $(17)$ & $(49)$ & $(76)$ & $(38)$ \\
\hline [We have choices in the selection of readings (articles, & 1.1 & 6.6 & 22.1 & 45.3 & 24.9 \\
books) that drive discussion group formation] & $(2)$ & $(12)$ & $(40)$ & $(82)$ & $(45)$ \\
\hline [We post audio and/or video files in threaded & 5.5 & 8.3 & 24.3 & 39.2 & 22.7 \\
discussions instead of only written responses] & $(10)$ & $(15)$ & $(44)$ & $(71)$ & $(41)$ \\
\hline [We interact with peers through student presentations & 1.7 & 5.0 & 28.2 & 40.9 & 24.3 \\
(asynchronously or synchronously).] & $(3)$ & $(9)$ & $(51)$ & $(74)$ & $(44)$ \\
\hline [We work collaboratively using online communication & 1.1 & 6.6 & 15.5 & 44.8 & 32.0 \\
tools to complete case studies, projects, reports, etc.] & $(2)$ & $(12)$ & $(28)$ & $(81)$ & $(58)$ \\
\hline [We were allowed to peer-review our classmates' & 1.1 & 9.4 & 18.8 & 45.9 & 24.9 \\
work.] & $(2)$ & $(17)$ & $(34)$ & $(83)$ & $(45)$ \\
\hline [We could rate the individual performance of our team & 2.8 & 8.8 & 17.1 & & 40.9 \\
members on projects.] & $(5)$ & $(16)$ & $(31)$ & $(74)$ & $(55)$ \\
\hline
\end{tabular}

Overall, from the data shown in the table above, it was reported that collaboratively using online communication tools to complete case studies, projects, reports, etc. was the most engaging aspect for learner-tolearner engagement. The aspect recorded the highest percentage of positive reactions by the respondents. The majority of the respondents $76.8 \%$ (139) reacted positively to the aspect while $15.5 \%$ (28) were neutral and the remaining $7.7 \%$ (14) reacted negatively.

As for the least engaging aspect for learner-to-learner engagement, it was found that giving the opportunity for students to introduce themselves using an icebreaker discussion had the lowest percentage of positive reaction by the respondents. From the data, $52.5 \%(95)$ had a positive reaction towards the aspect and it was followed by $31.5 \%(57)$ being neutral and $16.1 \%(29)$ with a negative reaction.

\subsection{Learner-to-Instructor Engagement}

Table 3 shows the summary of responses in percentage and frequency on learner-to-instructor engagement strategy. 
Table-3. Summary of responses in percentage and frequency on learner-to-instructor engagement strategy.

\begin{tabular}{|c|c|c|c|c|c|}
\hline \multirow[t]{2}{*}{ Statements } & \multicolumn{5}{|c|}{ Percentage (\%) / Frequency (N) } \\
\hline & Never & Rarely & Sometimes & Very Often & Always \\
\hline $\begin{array}{l}\text { [The instructor refers to students by name in } \\
\text { discussion forums.] }\end{array}$ & $\begin{array}{l}0.6 \\
(1)\end{array}$ & $\begin{array}{c}6.1 \\
(11)\end{array}$ & $\begin{array}{l}23.2 \\
(42)\end{array}$ & $\begin{array}{l}37.0 \\
(67)\end{array}$ & $\begin{array}{l}33.1 \\
(60)\end{array}$ \\
\hline $\begin{array}{l}\text { [The instructor sends/posts regular announcements } \\
\text { or email reminders.] }\end{array}$ & $\begin{array}{l}0 \\
(0)\end{array}$ & $\begin{array}{l}5.0 \\
(9) \\
\end{array}$ & $\begin{array}{l}12.2 \\
(22) \\
\end{array}$ & $\begin{array}{l}44.8 \\
(81) \\
\end{array}$ & $\begin{array}{l}38.1 \\
(69) \\
\end{array}$ \\
\hline $\begin{array}{l}\text { [The instructor creates a forum for students to } \\
\text { contact the instructor with questions about the } \\
\text { course.] }\end{array}$ & $\begin{array}{c}6 \\
(1)\end{array}$ & $\begin{array}{l}3.9 \\
(7)\end{array}$ & $\begin{array}{l}16.0 \\
(29)\end{array}$ & $\begin{array}{l}48.6 \\
(88)\end{array}$ & $\begin{array}{l}30.9 \\
(56)\end{array}$ \\
\hline $\begin{array}{l}\text { [The instructor creates a course orientation for } \\
\text { students.] }\end{array}$ & $\begin{array}{c}0 \\
(0)\end{array}$ & $\begin{array}{l}4.4 \\
(8)\end{array}$ & $\begin{array}{l}22.1 \\
(40)\end{array}$ & $\begin{array}{l}44.2 \\
(80)\end{array}$ & $\begin{array}{l}29.3 \\
(53)\end{array}$ \\
\hline $\begin{array}{l}\text { [The instructor posts a "due date checklist" at the } \\
\text { end of each instructional unit] }\end{array}$ & $\begin{array}{l}2.2 \\
(4)\end{array}$ & $\begin{array}{l}5.0 \\
(9)\end{array}$ & $\begin{array}{l}14.4 \\
(26)\end{array}$ & $\begin{array}{l}40.3 \\
(73)\end{array}$ & $\begin{array}{l}38.1 \\
(69)\end{array}$ \\
\hline $\begin{array}{l}\text { [The instructor creates short videos to increase } \\
\text { instructor presence in the course.] }\end{array}$ & $\begin{array}{c}6.1 \\
(11) \\
\end{array}$ & $\begin{array}{l}8.3 \\
(15) \\
\end{array}$ & $\begin{array}{l}22.7 \\
(41) \\
\end{array}$ & $\begin{array}{l}38.1 \\
(69) \\
\end{array}$ & $\begin{array}{l}24.9 \\
(45) \\
\end{array}$ \\
\hline $\begin{array}{l}\text { [The instructor provides feedback using various } \\
\text { modalities (e.g., text, audio, } 4.050 .88 \text { video, and } \\
\text { visuals).] }\end{array}$ & $\begin{array}{l}2.2 \\
(4)\end{array}$ & $\begin{array}{c}6.6 \\
(12)\end{array}$ & $\begin{array}{l}21.5 \\
(39)\end{array}$ & $\begin{array}{l}41.4 \\
(75)\end{array}$ & $\begin{array}{l}28.2 \\
(51)\end{array}$ \\
\hline $\begin{array}{l}\text { [The instructor provides students with an } \\
\text { opportunity to reflect (e.g., via a journal or } \\
\text { surveys).] }\end{array}$ & $\begin{array}{l}1.1 \\
(2)\end{array}$ & $\begin{array}{c}8.3 \\
(15)\end{array}$ & $\begin{array}{l}19.9 \\
(36)\end{array}$ & $\begin{array}{l}40.9 \\
(74)\end{array}$ & $\begin{array}{l}29.8 \\
(54)\end{array}$ \\
\hline $\begin{array}{l}\text { [The instructor posts grading rubrics for all } \\
\text { assignments] }\end{array}$ & $\begin{array}{l}1.7 \\
(3)\end{array}$ & $\begin{array}{c}7.2 \\
(13) \\
\end{array}$ & $\begin{array}{l}18.2 \\
(33) \\
\end{array}$ & $\begin{array}{l}41.4 \\
(75) \\
\end{array}$ & $\begin{array}{l}31.5 \\
(57) \\
\end{array}$ \\
\hline $\begin{array}{l}\text { [The instructor uses various features in } \\
\text { synchronous sessions to interact with students (e.g., } \\
\text { polls, emoticons, whiteboard, text, or audio and } \\
\text { video chat).] }\end{array}$ & $\begin{array}{l}0.6 \\
(1)\end{array}$ & $\begin{array}{c}6.1 \\
(11)\end{array}$ & $\begin{array}{l}22.1 \\
(40)\end{array}$ & $\begin{array}{l}40.9 \\
(74)\end{array}$ & $\begin{array}{l}30.4 \\
(55)\end{array}$ \\
\hline
\end{tabular}

Table-4. Summary of responses in percentage and frequency on learner-to-content engagement strategy.

\begin{tabular}{|c|c|c|c|c|c|}
\hline \multirow[t]{2}{*}{ Statements } & \multicolumn{5}{|c|}{ Percentage (\%) / Frequency (N) } \\
\hline & Never & Rarely & Sometimes & Very Often & Always \\
\hline $\begin{array}{l}\text { [We could interact with the content of the lesson } \\
\text { in more than one format (e.g., text, video, audio, } \\
\text { interactive games, or simulations)] }\end{array}$ & $\begin{array}{l}\mathrm{O} \\
(\mathrm{O})\end{array}$ & $\begin{array}{l}5.0 \\
(9)\end{array}$ & $\begin{array}{l}25.4 \\
(46)\end{array}$ & $\begin{array}{l}41.4 \\
(75)\end{array}$ & $\begin{array}{l}28.2 \\
(51)\end{array}$ \\
\hline $\begin{array}{l}\text { [We could use optional online resources to explore } \\
\text { topics in more depth.] }\end{array}$ & $\begin{array}{c}0 \\
(0)\end{array}$ & $\begin{array}{l}2.8 \\
(5)\end{array}$ & $\begin{array}{l}22.1 \\
(40)\end{array}$ & $\begin{array}{l}41.4 \\
(75)\end{array}$ & $\begin{array}{l}33.7 \\
(61)\end{array}$ \\
\hline $\begin{array}{l}\text { [We could experience live, synchronous web } \\
\text { conferencing for class events and/or guest talks.] }\end{array}$ & $\begin{array}{c}\mathrm{O} \\
(\mathrm{O})\end{array}$ & $\begin{array}{l}0.6 \\
(1)\end{array}$ & $\begin{array}{l}4.4 \\
(8)\end{array}$ & $\begin{array}{l}24.3 \\
(44)\end{array}$ & $\begin{array}{l}39.8 \\
(72)\end{array}$ \\
\hline $\begin{array}{l}\text { [Discussions are structured with guiding questions } \\
\text { and/or prompts to deepen our understanding of the } \\
\text { content.] }\end{array}$ & $\begin{array}{c}\mathrm{O} \\
(\mathrm{O})\end{array}$ & $\begin{array}{c}6.1 \\
(11)\end{array}$ & $\begin{array}{l}23.2 \\
(42)\end{array}$ & $\begin{array}{l}40.9 \\
(74)\end{array}$ & $\begin{array}{l}29.8 \\
(54)\end{array}$ \\
\hline $\begin{array}{l}\text { [We could research an approved topic and present } \\
\text { our findings in a delivery method of our choice } \\
\text { (e.g., discussions forum, chat, web conference, } \\
\text { multimedia presentation).] }\end{array}$ & $\begin{array}{c}0 \\
(0)\end{array}$ & $\begin{array}{l}3.9 \\
(7)\end{array}$ & $\begin{array}{l}21.0 \\
(38)\end{array}$ & $\begin{array}{l}43.1 \\
(78)\end{array}$ & $\begin{array}{l}32.0 \\
(58)\end{array}$ \\
\hline $\begin{array}{l}\text { [We could search for and select applicable } \\
\text { materials (e.g., articles, books) based on their } \\
\text { interests.] }\end{array}$ & $\begin{array}{c}0 \\
(0)\end{array}$ & $\begin{array}{l}4.4 \\
(8)\end{array}$ & $\begin{array}{l}19.9 \\
(36)\end{array}$ & $\begin{array}{l}43.6 \\
(79)\end{array}$ & $\begin{array}{l}32.0 \\
(58)\end{array}$ \\
\hline $\begin{array}{l}\text { [We were given an opportunity to reflect on } \\
\text { important elements of the course (e.g., use of } \\
\text { communication tools, their learning, team projects, } \\
\text { and community).] }\end{array}$ & $\begin{array}{c}0 \\
(0)\end{array}$ & $\begin{array}{c}6.1 \\
(11)\end{array}$ & $\begin{array}{l}22.1 \\
(40)\end{array}$ & $\begin{array}{l}41.4 \\
(75)\end{array}$ & $\begin{array}{l}30.4 \\
(55)\end{array}$ \\
\hline $\begin{array}{l}\text { [We could work on realistic scenarios to apply } \\
\text { content (e.g., case studies, reports, research papers, } \\
\text { presentations, client projects).] }\end{array}$ & $\begin{array}{c}\mathrm{O} \\
(\mathrm{O})\end{array}$ & $\begin{array}{c}6.1 \\
(11)\end{array}$ & $\begin{array}{l}23.8 \\
(43)\end{array}$ & $\begin{array}{l}40.9 \\
(74)\end{array}$ & $\begin{array}{l}29.3 \\
(53)\end{array}$ \\
\hline $\begin{array}{l}\text { [We were given self-tests to check our } \\
\text { understanding of materials. }]\end{array}$ & $\begin{array}{l}2.2 \\
(4)\end{array}$ & $\begin{array}{l}7.2 \\
(13)\end{array}$ & $\begin{array}{l}22.1 \\
(40)\end{array}$ & $\begin{array}{l}37.6 \\
(68)\end{array}$ & $\begin{array}{l}30.9 \\
(56)\end{array}$ \\
\hline
\end{tabular}


Based on the table above, it was reported that the instructor's effort of sending/posting regular announcements or email reminders was viewed as the most engaging aspect for learner-to-instructor engagement with the highest percentage of positive reaction. This is due to the majority of the respondents, $82.9 \%$ (150) reacted positively to the aspect. Meanwhile, 12.2\% (22) were neutral and only 5\% (9) reacted negatively.

It was also reported that the least engaging aspect was the instructor's effort to create short videos to increase instructor presence in the course, as it had the least percentage of positive reaction compared to other aspects in the engagement strategy. The aspect recorded 63\%(114) reacting positively and followed by $22.7 \%(41)$ being neutral while the remaining $14.4 \%$ (26) reacting negatively.

\subsection{Learner-to-Content Engagement}

Table 4 shows the summary of responses in percentage and frequency on learner-to-content engagement strategy.

From the table above, it can be seen that the students' ability to search for and select applicable materials (e.g., articles, books) based on their interests was voted as the most engaging aspect in learner-to-content engagement. This aspect recorded the highest percentage of positive reactions compared to others. Most of the respondents $75.6 \%$ (138) had a positive reaction towards the aspect and it was then followed by $19.9 \%$ (36) with a neutral reaction while the remaining $4.4 \%(7)$ had a negative reaction.

Meanwhile, the least engaging aspect was when the students were given self-tests to check their understanding of materials. This aspect recorded the lowest percentage of positive reactions by the respondents. Only 68.5\% (123) reacted positively to the aspect while $22.1 \%(40)$ were neutral and the remaining $9.4 \%$ (17) reacted negatively.

As for the second research question on the correlations between learner-to-learner, learner-to-instructor and learner-to-content engagement strategies, Pearson Correlation tests were conducted among the three engagement strategies (learner-to-learner, learner-to-instructor, and learner-to-content).

Table 5 shows the Pearson Correlation between learner-to-learner engagement and learner-to-instructor engagement. From the table, it was reported that there was a strong positive significant relationship between learner-to-learner engagement and learner-to-instructor engagement, $\mathrm{p}=<0.01, \mathrm{r}=.804$. In conclusion, reaction towards learner-to-learner engagement strategy can be highly influenced by learner-to-instructor engagement strategy.

Table-5. Pearson correlation between learner-to-learner engagement and learner-to-instructor engagement.

\begin{tabular}{l|l|r|r}
\hline Correlations. & \multicolumn{1}{l}{ Pearson Correlation } & 1 & $0.804^{* *}$ \\
\hline Mean Score of Learner-Learner Interactions & Sig. (2-tailed) & 0.000 \\
\cline { 2 - 4 } & $\mathrm{N}$ & 181 & 181 \\
\hline Mean Score of Learner-Instructor Interactions & Pearson Correlation & $0.804^{* *}$ & 1 \\
\cline { 2 - 4 } & Sig. (2-tailed) & 0.000 & 181 \\
\cline { 2 - 4 } & $\mathrm{N}$ & 181 \\
\hline Note: **. Correlation is significant at the 0.01 level (2-tailed). & &
\end{tabular}

As for the next relationship, Table 6 shows the Pearson correlation between learner-to-learner engagement and learner-to-content engagement. As reported, there was a strong positive significant relationship between the learner-to-learner engagement and learner-to-content engagement, $\mathrm{p}=<0.01, \mathrm{r}=.733$. Thus, it can be inferred that reaction towards learner-to-learner engagement strategy can be influenced by leaner-to-content engagement strategy.

Finally, Table 7 shows the Pearson correlation between learner-to-instructor engagement and learner-tocontent engagement. From the data, it was shown that there was a strong positive significant relationship between the learner-to-instructor engagement and learner-to-content engagement, $\mathrm{p}=<0.01, \mathrm{r}=.753$. It can be concluded 
that reaction towards learner-to-instructor engagement strategy can be influenced by learner-to-content engagement strategy.

Table-6. Pearson correlation between learner-to-learner engagement and learner-to-content engagement.

\begin{tabular}{l|l|c|c}
\hline \multicolumn{2}{l}{ Correlations } & \multicolumn{1}{c}{} \\
\hline \multicolumn{2}{|l}{} & $\begin{array}{c}\text { Mean Score of } \\
\text { Learner-Learner } \\
\text { Interactions }\end{array}$ & $\begin{array}{c}\text { Mean Score of } \\
\text { Learner-Content } \\
\text { Interactions }\end{array}$ \\
\hline \multirow{2}{*}{ Mean Score of Learner-Learner Interactions } & Pearson Correlation & 1 & $0.733^{* * *}$ \\
\cline { 2 - 4 } & Sig. (2-tailed) & & 0.000 \\
\cline { 2 - 4 } & $\mathrm{N}$ & 181 & 181 \\
\hline Mean Score of Learner-Content Interactions & Pearson Correlation & $0.733^{* *}$ & 1 \\
\cline { 2 - 4 } & Sig. (2-tailed) & 0.000 & 181 \\
\cline { 2 - 4 } & $\mathrm{N}$ & 181 & \\
\hline
\end{tabular}

Note: ${ }^{*} *$. Correlation is significant at the 0.01 level (2-tailed).

Table-7. Pearson correlation between learner-to-instructor engagement and learner-to-content engagement.

\begin{tabular}{|c|c|c|c|}
\hline \multicolumn{4}{|l|}{ Correlations } \\
\hline & & $\begin{array}{c}\text { Mean Score of } \\
\text { Learner-Instructor } \\
\text { Interactions }\end{array}$ & $\begin{array}{c}\text { Mean Score of } \\
\text { Learner-Content } \\
\text { Interactions } \\
\end{array}$ \\
\hline \multirow{3}{*}{$\begin{array}{l}\text { Mean Score of Learner-Instructor } \\
\text { Interactions }\end{array}$} & Pearson Correlation & 1 & $0.753^{* *}$ \\
\hline & Sig. (2-tailed) & & 0.000 \\
\hline & $\mathrm{N}$ & 181 & 181 \\
\hline \multirow{3}{*}{$\begin{array}{l}\text { Mean Score of Learner-Content } \\
\text { Interactions }\end{array}$} & Pearson Correlation & $0.753^{* *}$ & 1 \\
\hline & Sig. (2-tailed) & 0.000 & \\
\hline & $\mathrm{N}$ & 181 & 181 \\
\hline
\end{tabular}

\subsection{Student Perceptions towards the Engagement Strategies with the Course Enrolled}

To address the third research question on the significant mean differences in the perceptions towards engagement strategies based on the programme enrolled, a one-way ANOVA test was conducted to find the significant mean differences between the programmes enrolled by the students with the reactions towards the engagement strategies.

Table 8 shows the results of the one-way ANOVA test on the engagement strategies based on the programmes enrolled. Pertinent to the learner-to-learner engagement strategy, it was reported from the results in the table below that there was a statistically significant mean difference between the groups as this was determined by oneway ANOVA F $(3,177)=5.447, \mathrm{p}<0.05$. Thus, it can be concluded that programmes enrolled influenced the reactions towards the learner-to-learner engagement strategy. As for the next engagement strategy which is the learner-to-instructor engagement strategy, it was also shown that there was a statistically significant mean difference between the groups as determined by one-way ANOVA F $(3,177)=7.139$, p $<0.05$. Thus, it can be inferred that programmes enrolled also influenced the reactions towards the learner-to-instructor engagement strategy. Last but not least, for the engagement strategy of learner-to-content, it was reported that there was also a statistically significant mean difference between the groups as determined by one-way $\operatorname{ANOVA~F}(3,177)=8.092$, $\mathrm{p}<0.05$. Thus, it can also be concluded that programmes enrolled influenced the reactions towards learner-tocontent engagement strategy. Overall, a conclusion can be made that programmes enrolled influenced all three of the engagement strategies.

Since there were significant mean differences between the programmes enrolled with all three of the engagement strategies (learner-to-learner, learner-to-instructor and learner-to-content), Tukey HSD post hoc test was conducted to further understand the results. Table 9 shows the results of the Tukey HSD post hoc test on engagement strategies based on the programmes enrolled. 
Table-8. Results of one-way ANOVA test on engagement strategies based on programmes enrolled.

\begin{tabular}{|c|c|c|c|c|c|c|}
\hline \multicolumn{7}{|l|}{ ANOVA } \\
\hline & & Sum of Squares & df & Mean Square & $\mathbf{F}$ & Sig. \\
\hline \multirow{3}{*}{$\begin{array}{l}\text { Mean Score of Learner-Learner } \\
\text { Interactions }\end{array}$} & Between Groups & 10.001 & 3 & 3.334 & 5.447 & 0.001 \\
\hline & Within Groups & 108.322 & 177 & 0.612 & & \\
\hline & Total & 118.323 & 180 & & & \\
\hline \multirow{3}{*}{$\begin{array}{l}\text { Mean Score of Learner-Instructor } \\
\text { Interactions }\end{array}$} & Between Groups & 12.094 & 3 & 4.031 & 7.139 & 0.000 \\
\hline & Within Groups & 99.953 & 177 & 0.565 & & \\
\hline & Total & 112.046 & 180 & & & \\
\hline \multirow{3}{*}{$\begin{array}{l}\text { Mean Score of Learner-Content } \\
\text { Interactions }\end{array}$} & Between Groups & 12.965 & 3 & 4.322 & 8.092 & 0.000 \\
\hline & Within Groups & 94.524 & 177 & 0.534 & & \\
\hline & Total & 107.489 & 180 & & & \\
\hline
\end{tabular}

Table-9. Results of Tukey HSD Post Hoc test on learner-to-learner engagement strategy across programmes enrolled.

\begin{tabular}{|c|c|c|c|c|c|c|}
\hline \multicolumn{7}{|c|}{ Multiple Comparisons } \\
\hline \multicolumn{7}{|c|}{ Dependent Variable: Mean Score of Learner-Learner Interactions } \\
\hline \multicolumn{7}{|l|}{ Tukey HSD } \\
\hline \multirow[b]{2}{*}{ (I) Programme } & \multirow[b]{2}{*}{ (J) Programme } & \multirow{2}{*}{$\begin{array}{c}\text { Mean } \\
\text { Difference } \\
(\mathbf{I}-\mathbf{J})\end{array}$} & \multirow[b]{2}{*}{$\begin{array}{l}\text { Std. } \\
\text { Error }\end{array}$} & \multirow[b]{2}{*}{ Sig. } & \multicolumn{2}{|c|}{ 95\% Confidence Interval } \\
\hline & & & & & $\begin{array}{l}\text { Lower } \\
\text { Bound }\end{array}$ & $\begin{array}{l}\text { Upper } \\
\text { Bound }\end{array}$ \\
\hline \multirow{3}{*}{$\begin{array}{l}\text { Chemical } \\
\text { Engineering }\end{array}$} & Civil Engineering & 0.11463 & 0.15519 & 0.881 & -0.2879 & 0.5171 \\
\hline & $\begin{array}{c}\text { Electrical } \\
\text { Engineering }\end{array}$ & 0.31574 & 0.15790 & 0.192 & -0.0938 & 0.7253 \\
\hline & $\begin{array}{l}\text { Mechanical } \\
\text { Engineering }\end{array}$ & -0.38802 & 0.17127 & 0.110 & -0.8322 & 0.0562 \\
\hline \multirow[t]{3}{*}{ Civil Engineering } & $\begin{array}{c}\text { Chemical } \\
\text { Engineering }\end{array}$ & -0.11463 & 0.15519 & 0.881 & -0.5171 & 0.2879 \\
\hline & $\begin{array}{c}\text { Electrical } \\
\text { Engineering }\end{array}$ & 0.20111 & 0.16233 & 0.603 & -0.2199 & 0.6221 \\
\hline & $\begin{array}{c}\text { Mechanical } \\
\text { Engineering }\end{array}$ & $-0.50265^{*}$ & 0.17536 & 0.024 & -0.9574 & -0.0478 \\
\hline \multirow[t]{3}{*}{$\begin{array}{l}\text { Electrical } \\
\text { Engineering }\end{array}$} & $\begin{array}{c}\text { Chemical } \\
\text { Engineering }\end{array}$ & -0.31574 & 0.15790 & 0.192 & -0.7253 & 0.0938 \\
\hline & Civil Engineering & -0.20111 & 0.16233 & 0.603 & -0.6221 & 0.2199 \\
\hline & $\begin{array}{c}\text { Mechanical } \\
\text { Engineering }\end{array}$ & $-0.70376^{*}$ & 0.17776 & 0.001 & -1.1648 & -0.2427 \\
\hline \multirow[t]{3}{*}{$\begin{array}{l}\text { Mechanical } \\
\text { Engineering }\end{array}$} & $\begin{array}{c}\text { Chemical } \\
\text { Engineering }\end{array}$ & 0.38802 & 0.17127 & 0.110 & -0.0562 & 0.8322 \\
\hline & Civil Engineering & $0.50265^{*}$ & 0.17536 & 0.024 & 0.0478 & 0.9574 \\
\hline & $\begin{array}{c}\text { Electrical } \\
\text { Engineering }\end{array}$ & $0.70376^{*}$ & 0.17776 & 0.001 & 0.2427 & 1.1648 \\
\hline
\end{tabular}

Note: *. The mean difference is significant at the 0.05 level.

Tukey HSD post hoc test showed that students enrolled in Mechanical Engineering had more positive perceptions towards learner-to-learner engagement strategy than those in Civil Engineering $(\mathrm{MD}=0.50265$, $\mathrm{p}=0.024)$ and those in Electrical Engineering $(\mathrm{MD}=.070376, \mathrm{p}=0.001)$. However, they had equal perceptions than those in Chemical Engineering ( $\mathrm{MD}=0.38802, \mathrm{p}=0.110$ ). Those in Chemical Engineering also had equal perceptions than those in Civil Engineering $(\mathrm{MD}=0.11463, \mathrm{p}=0.881$ and those in Electrical Engineering $(\mathrm{MD}=0.31574$, $\mathrm{p}=0.192)$. Meanwhile, those in Civil Engineering also had equal perceptions than those in Electrical Engineering $(\mathrm{MD}=0.20111, \mathrm{p}=0.603)$. In Table 10 Tukey HSD post hoc test indicated that students enrolled in Mechanical Engineering had more positive perceptions towards learner-to-instructor engagement strategy than those in all other three programmes; Chemical Engineering $(\mathrm{MD}=0.55403, \mathrm{p}=0.005)$, Civil Engineering $(\mathrm{MD}=0.53713$, $\mathrm{p}=0.009$ ) and Electrical Engineering $(\mathrm{MD}=0.77366, \mathrm{p}=0.000)$. Those in Chemical Engineering had equal perceptions than those in Civil Engineering $(\mathrm{MD}=0.01690, \mathrm{p}=0.999$ and those in Electrical Engineering 
$(\mathrm{MD}=0.21963, \mathrm{p}=0.471)$. Meanwhile, those in Civil Engineering also had equal perceptions than those in Electrical Engineering $(\mathrm{MD}=0.26253, \mathrm{p}=0.430)$.

Table-10. Results of Tukey HSD Post Hoc test on learner-to-instructor engagement strategy across programmes enrolled

\begin{tabular}{|c|c|c|c|c|c|c|}
\hline \multirow{2}{*}{\multicolumn{7}{|c|}{$\begin{array}{l}\text { Multiple Comparisons } \\
\text { Dependent Variable: Mean Score of Learner-Instructor Interactions }\end{array}$}} \\
\hline & & & & & & \\
\hline \multicolumn{7}{|l|}{ Tukey HSD } \\
\hline \multirow[b]{2}{*}{$\begin{array}{l}\text { (I) } \\
\text { Programme }\end{array}$} & \multirow[b]{2}{*}{ (J) Programme } & \multirow{2}{*}{$\begin{array}{c}\text { Mean } \\
\text { Difference } \\
(\mathbf{I}-\mathbf{J})\end{array}$} & \multirow[b]{2}{*}{$\begin{array}{l}\text { Std. } \\
\text { Error }\end{array}$} & \multirow[b]{2}{*}{ Sig. } & \multicolumn{2}{|c|}{ 95\% Confidence Interval } \\
\hline & & & & & $\begin{array}{l}\text { Lower } \\
\text { Bound }\end{array}$ & Upper Bound \\
\hline \multirow{3}{*}{$\begin{array}{l}\text { Chemical } \\
\text { Engineering }\end{array}$} & Civil Engineering & -0.01690 & 0.14907 & 0.999 & -0.4035 & 0.3697 \\
\hline & Electrical Engineering & 0.21963 & 0.15168 & 0.471 & -0.1738 & 0.6130 \\
\hline & Mechanical Engineering & $-0.55403^{*}$ & 0.16452 & 0.005 & -0.9807 & -0.1273 \\
\hline \multirow{3}{*}{$\begin{array}{l}\text { Civil } \\
\text { Engineering }\end{array}$} & Chemical Engineering & 0.01690 & 0.14907 & 0.999 & -0.3697 & 0.4035 \\
\hline & Electrical Engineering & 0.23653 & 0.15593 & 0.430 & -0.1679 & 0.6409 \\
\hline & Mechanical Engineering & $-0.53713^{*}$ & 0.16844 & 0.009 & -0.9740 & -0.1003 \\
\hline \multirow{3}{*}{$\begin{array}{l}\text { Electrical } \\
\text { Engineering }\end{array}$} & Chemical Engineering & -0.21963 & 0.15168 & 0.471 & -0.6130 & 0.1738 \\
\hline & Civil Engineering & -0.23653 & 0.15593 & 0.430 & -0.6409 & 0.1679 \\
\hline & Mechanical Engineering & $-0.77366^{*}$ & 0.17076 & 0.000 & -1.2165 & -0.3308 \\
\hline \multirow{3}{*}{$\begin{array}{l}\text { Mechanical } \\
\text { Engineering }\end{array}$} & Chemical Engineering & $0.55403^{*}$ & 0.16452 & 0.005 & 0.1273 & 0.9807 \\
\hline & Civil Engineering & $0.53713^{*}$ & 0.16844 & 0.009 & 0.1003 & 0.9740 \\
\hline & Electrical Engineering & $0.77366^{*}$ & 0.17076 & 0.000 & 0.3308 & 1.2165 \\
\hline
\end{tabular}

Note: *. The mean difference is significant at the 0.05 level.

Table-1 1. Results of Tukey HSD Post Hoc Test on Learner-to-content Engagement Strategy across Programmes Enrolled

\begin{tabular}{|c|c|c|c|c|c|c|}
\hline \multicolumn{7}{|c|}{ Multiple Comparisons } \\
\hline \multicolumn{7}{|c|}{ Dependent Variable: Mean score of learner-content interactions } \\
\hline \multicolumn{7}{|l|}{ Tukey HSD } \\
\hline \multirow[b]{2}{*}{$\begin{array}{l}\text { (I) } \\
\text { Programme }\end{array}$} & \multirow[b]{2}{*}{ (J) Programme } & \multirow{2}{*}{$\begin{array}{l}\text { Mean } \\
\text { Difference } \\
(\mathbf{I}-\mathbf{J})\end{array}$} & \multirow[b]{2}{*}{$\begin{array}{l}\text { Std. } \\
\text { Error }\end{array}$} & \multirow[b]{2}{*}{ Sig. } & \multicolumn{2}{|c|}{ 95\% Confidence Interval } \\
\hline & & & & & $\begin{array}{l}\text { Lower } \\
\text { Bound }\end{array}$ & Upper Bound \\
\hline \multirow{3}{*}{$\begin{array}{l}\text { Chemical } \\
\text { Engineering }\end{array}$} & Civil Engineering & -0.05361 & 0.14497 & 0.983 & -0.4296 & 0.3224 \\
\hline & Electrical Engineering & 0.08856 & 0.14750 & 0.932 & -0.2940 & 0.4711 \\
\hline & Mechanical Engineering & $-0.66288^{*}$ & 0.15999 & 0.000 & -1.0778 & -0.2479 \\
\hline \multirow{3}{*}{$\begin{array}{l}\text { Civil } \\
\text { Engineering }\end{array}$} & Chemical Engineering & 0.05361 & 0.14497 & 0.983 & -0.3224 & 0.4296 \\
\hline & Electrical Engineering & 0.14217 & 0.15163 & 0.785 & -0.2511 & 0.5354 \\
\hline & Mechanical Engineering & $-0.60926^{*}$ & 0.16381 & 0.002 & -1.0341 & -0.1844 \\
\hline \multirow{3}{*}{$\begin{array}{l}\text { Electrical } \\
\text { Engineering }\end{array}$} & Chemical Engineering & -0.08856 & 0.14750 & 0.932 & -0.4711 & 0.2940 \\
\hline & Civil Engineering & -0.14217 & 0.15163 & 0.785 & -0.5354 & 0.2511 \\
\hline & Mechanical Engineering & $-0.75143^{*}$ & 0.16606 & 0.000 & -1.1821 & -0.3207 \\
\hline \multirow{3}{*}{$\begin{array}{l}\text { Mechanical } \\
\text { Engineering }\end{array}$} & Chemical Engineering & $0.66288^{*}$ & 0.15999 & 0.000 & 0.2479 & 1.0778 \\
\hline & Civil Engineering & $0.60926^{*}$ & 0.16381 & 0.002 & 0.1844 & 1.0341 \\
\hline & Electrical Engineering & $0.75143^{*}$ & 0.16606 & 0.000 & 0.3207 & 1.1821 \\
\hline
\end{tabular}

Note: *. The mean difference is significant at the 0.05 level.

In Table 11 Tukey HSD post hoc test revealed that students enrolled in Mechanical Engineering had more positive perceptions towards learner-to-instructor engagement strategy than those in all other three programmes; Chemical Engineering $(\mathrm{MD}=0.66288, \mathrm{p}=0.000)$, Civil Engineering $(\mathrm{MD}=0.60926, \mathrm{p}=0.002)$ and Electrical Engineering $(\mathrm{MD}=0.75143, \mathrm{p}=0.000)$. Those in Chemical Engineering had equal perceptions than those in Civil Engineering $(\mathrm{MD}=0.05361, \mathrm{p}=0.983$ and those in Electrical Engineering $(\mathrm{MD}=0.08856, \mathrm{p}=0.932)$. Meanwhile, those in Civil Engineering also had equal perceptions than those in Electrical Engineering $(\mathrm{MD}=0.14217, \mathrm{p}=0.785)$.

Thus, from the results reported, it can be concluded that Mechanical Engineering students showed positive feedback towards all three of the engagement strategies: learner-to-learner, learner-to-instructor and learner-tocontent.

\section{CONCLUSION}

Student engagement is essential in online learning because it improves student satisfaction and motivates them to learn especially during ODL. In this research, students felt that learner-content was the most engaging strategy. 
This was followed by learner-instructor interactions while learner-learner interactions were viewed as the least engaging strategy. Learner-content interaction is a type of interaction in the distance education process that includes various methods and approaches for introducing students to the material, which can be in the form of text, audio, video, computer simulation/application, and so on. In essence, the students are aware of the open possibilities for widely available information, but the information itself does not imply perceived knowledge. As a result, learner-content interaction is critical for the entire educational process. In ODL, the students were able to search for and select applicable materials (e.g., articles, books) based on their interests. This category was voted as the most engaging aspect in learner-to-content engagement. The finding of this research is in agreement with AbouKhalil et al. (2021). Learner-instructor interaction is another important aspect that can lead to meaningful online learning. The students need their instructor to guide, motivate and facilitate their learning. The instructor's effort of sending/posting regular announcements or email reminders was viewed as the most engaging aspect for learnerto-instructor engagement with the highest percentage of positive reaction. Shackelford and Maxwell (2012) state that regardless of the format, students value the instructor's guidance during discussions. When students know that their contributions to a discussion are being reviewed and considered by the instructor, they may feel more a part of a learning community. They gain from knowing that the conversation is being steered in a thoughtful and informed direction. Although students have different preferences in their engagement strategies, inevitably, all three engagement strategies (learner-to-learner, learner-to-instructor and learner-to-content) are interdependent. One sole engagement strategy may not pose effective with the absence of the other two. Learner-to-learner engagement strategy is heavily influenced by learner-to-instructor engagement strategy. As instructors had transmitted relevant content to the students, just then they are able to refer to their peers as a supplementary point of reference. Thus, instructors should be highly attentive in delivering the right education content to the students since the process of knowledge transmission does not occur from instructor-to-learner only but also through other mediums such as learner-to-learner and learner-to-content. This is also aligned with research conducted by Ali (2020) who stated the three types of interactions, namely learner-to-learner, learner-to-instructor, and learner-to-content are necessary for effective online education Mechanical Engineering students in this research showed positive feedback towards all three of the engagement strategies: learner-to-learner, learner-to-instructor and learner-to-content. Fatehiboroujeni, Qattawi, and Goyal (2019) in his research among mechanical engineering students found that there are two potential strategies to encourage participation in online discussion forum which are attributing grade points as an incentive, or providing directives, examples, and structures for initiating various types of discussions in such an environment. They also discovered that students spent a significant time on lecture videos, homework, quizzes, and projects.

\section{LIMITATIONS AND FUTURE RESEARCH}

The present study has its limitation: it had a small sample size and it was a cross-sectional study using a survey. Because the sample was drawn from a group of engineering students, the results may not be applicable to students in other faculties, institutions, or contexts. Therefore, it is recommended that future research can have a bigger sample size, employ a longitudinal study using both quantitative and qualitative research design, and involve other students from different faculties. The use of qualitative methods, such as student interviews, would aid in the interpretation of quantitative results. Student open-ended responses may shed light on why some interaction types are rated as low or high importance. It is hoped that future research can give further insights into this area of study.

Funding: This study received no specific financial support.

Competing Interests: The authors declare that they have no competing interests.

Acknowledgement: All authors contributed equally to the conception and design of the study. 


\section{REFERENCES}

Abou-Khalil, V., Helou, S., Khalifé, E., Chen, M. A., Majumdar, R., \& Ogata, H. (2021). Emergency online learning in lowresource settings: Effective student engagement strategies. Education Sciences, 11(1), 24. Available at: https://doi.org/10.3390/educsci1 1010024.

Ali, S. (2020). Relationship between various forms of interaction and students' satisfaction in online learning: Case of an open university of Pakistan. Pakistan Journal of Distance and Online Learning, 6(2), 62-78.

Azlan, C. A., Wong, J. H. D., Tan, L. K., Huri, M. S. N. A., Ung, N. M., Pallath, V., \& Ng, K. H. (2020). Teaching and learning of postgraduate medical physics using Internet-based e-learning during the COVID-19 pandemic-A case study from Malaysia. Physica Medica, 80, 10-16. Available at: https://doi.org/10.1016/j.ejmp.2020.10.002.

Fatehiboroujeni, S., Qattawi, A., \& Goyal, S. (2019). Assessing and improving student engagement and motivation in mechanical engineering online courses. Paper presented at the 2019 ASEE Annual Conference \& Exposition, Tampa, Florida.

Garrison, D., Anderson, T., \& Archer, W. (1999). Critical inquiry in a text-based environment: Computer conferencing in higher education. The Internet and Higher Education, 2(2-3), 87-105. Available at: https://doi.org/10.1016/s10967516(00)00016-6.

Gray, J. A., \& DiLoreto, M. (2016). The effects of student engagement, student satisfaction, and perceived learning in online learning environments. International Journal of Educational Leadership Preparation, 11(1), 98-1 19.

Haron, H., Natrah, A. N. H., \& Harun, A. (2017). A conceptual model participatory engagement within E-learning community. Procedia Computer Science, 116, 242-250. Available at: https://doi.org/10.1016/j.procs.2017.10.046.

Ismail, N. S., Bakar, N. M., \& Wafa, S. W. (2020). Online learning challenges during pandemic COVID-19 in Malaysian higher learning institution. Universal Journal of Educational Research, 8(12), 7151-7159. Available at: https://doi.org/10.13189/ujer.2020.081282.

Khlaif, Z. N., Salha, S., \& Kouraichi, B. (2021). Emergency remote learning during COVID-19 crisis: Students' engagement. Education and Information Technologies, 1-23. Available at: https://doi.org/10.1007/s 10639-02 1-10566-4.

Martin, F., \& Bolliger, D. U. (2018). Engagement matters: Student perceptions on the importance of engagement strategies in the online learning environment. Online Learning, 22(1), 205-222. Available at: https://doi.org/10.24059/olj.v22i1.1092.

Martin, F., Wang, C., \& Sadaf, A. (2018). Student perception of helpfulness of facilitation strategies that enhance instructor presence, connectedness, engagement and learning in online courses. The Internet and Higher Education, 37, 52-65. Available at: https://doi.org/10.1016/j.iheduc.2018.01.003.

Mehall, S. (2020). Purposeful interpersonal interaction in online learning: What is it and how is it measured? Online Learning, 24(1), 182-204. Available at: https://doi.org/10.24059/olj.v24i1.2002.

Moore, G. E., Warner, W. J., \& Jone, D. W. (2016). Student-to-student interaction in distance education classes: What do graduate students want? Journal of Agrcultural Education, 57(2), 1-13. Available at: https://doi:10.5032/jae.2016.02001.

Moore, M. J. (1993). Three types of interaction. In K. Harry, M. John, \& D. Keegan (Eds.), Distance education theory. New York: Routledge.

Shackelford, J. L., \& Maxwell, M. (2012). Sense of community in graduate online education: Contribution of learner to learner interaction. International Review of Research in Open and Distributed Learning, 13(4), 228-249. Available at: https://doi.org/10.19173/irrodl.v13i4.1339.

Zhang, K., Wu, S., Xu, Y., Cao, W., Goetz, T., \& Parks-Stamm, E. (2020). Adaptability promotes student engagement under COVID-19: The multiple mediating effects of academic emotion. Frontiers in Psychology, 11, 633265-633265. Available at: https://doi.org/10.3389/fpsyg.2020.633265.

Views and opinions expressed in this article are the views and opinions of the author(s), International Journal of Asian Social Science shall not be responsible or answerable for any loss, damage or liability etc. caused in relation to/arising out of the use of the content. 